Kumawula, Vol. 3, No.3, Desember 2020, Hal 515 - 524 DOI: https://doi.org/10.24198/kumawula.v3i3.30552

ISSN 2620-844X (online)

Tersedia online di http://jurnal.unpad.ac.id/kumawula/index

\title{
PENGUATAN MINDSET EKONOMI MELALUI PENGELOLAAN POTENSI ALAM PRODUK KOLANG KALING DESA PAKIS, KENDAL, JAWA TENGAH
}

\author{
Ida Nur Aeni ${ }^{*}$, Partono Thomas ${ }^{2}$, Ita Nuryana ${ }^{3}$ \\ ${ }^{1}$ Universitas Negeri Semarang \\ ${ }^{2}$ Universitas Negeri Semarang \\ ${ }^{3}$ Universitas Negeri Semarang \\ *Korespondensi: idanuraeni@mail.unnes.ac.id
}

\begin{abstract}
Pakis Village is one of 16 villages in Limbangan Sub-district that have abundant natural resources potential. The superior products of Pakis Village are sugar palm fruit and palm sugar. However, efforts to develop the potential of the region and superior products have not been carried out optimally. The two main problems are the lack of the economic mindset and sub-optimal business development. The natural resource potential of palm trees is a great opportunity in building a business. Currently, sugar palm fruit products are only marketed in the absence of diversification of processed products. In fact, sugar palm fruit can be re-processed into other processed products that can increase the value added of products. It shows the need to increase human resources in Pakis Village especially in terms of strengthening economic mindset and literacy as well as the business management. Through strengthening economic literacy, this can increase the entrepreneurial spirit and a fundamental understanding of the role of the economy for society welfare. Through the utilization of abundant local natural resources in Pakis Village, the community can diversify the processed products of sugar palm fruit which can increase the value added of sugar palm fruit products.
\end{abstract}

Keywords: Economic Mindset; Economic Natural Potential; Sugar Palm Fruit; Entrepreneurial Spirit

\begin{abstract}
ABSTRAK
Desa Pakis merupakan salah satu dari 16 Desa di Kecamatan Limbangan yang memiliki potensi sumber daya alam melimpah. Produk unggulan Desa Pakis adalah kolang kaling dan gula aren. Namun upaya pengembangan potensi wilayah dan produk unggulan tersebut belum dilakukan secara optimal. Dua masalah utama yang dihadapi Desa Pakis terkait dengan bidang pengembangan ekonomi masyarakat adalah kurangnya penguatan pola pikir ekonomi masyarakat dalam pengelolaan potensi sumber daya lokal dan belum optimalnya pengembangan usaha dalam peningkatan daya saing produk unggulan. Potensi sumber daya alam tanaman aren menjadi peluang yang besar dalam membangun bisnis. Saat ini produk kolang kaling hanya dipasarkan bergitu saja tanpa adanya diversifikasi produk olahan. Padahal kolang kaling bisa diolah kembali menjadi produk olahan lain yang bisa meningkatkan nilai jual produk kolang kaling. Hal itu menunjukkan perlunya peningkatan sumber daya manusia di Desa Pakis terutama dalam hal penguatan mindset dan literasi ekonomi serta pengelolaan produk kolang kaling. Melalui penguatan literasi ekonomi ini dapat meningkatkan jiwa kewirausahaan dan pemahaman yang mendasar mengenai peran perekonomian untuk kesejahteraan masyarakat. Melalui pemanfaatan sumber daya alam lokal yang melimpah di Desa Pakis, yaitu produk kolang kaling maka masyarakat dapat melakukan diversifikasi produk olahan kolang kaling yang dapat meningkatkan nilai jual produk kolang kaling.
\end{abstract}

Kata Kunci: Mindset Ekonomi; Potensi Alam; Kolang Kaling; Jiwa Kewirausahaan 


\section{PENDAHULUAN}

Pembangunan pada dasarnya merupakan suatu usaha dan kegiatan yang dilakukan untuk menciptakan suatu keadaan yang lebih baik di masa yang akan datang (Basrowi \& Juariyah, 2010). Aspek perekonomian sangat berperan dalam peningkatan pembangunan suatu wilayah termasuk desa. Salah satu aspek yang harus diperhitungkan dalam pembangunan ekonomi daerah adalah kemampuan untuk memanfaatkan sumber daya manusia dan alam seektif dan seefisien mungkin (Junaidi \& Zulgani, 2011). Apalagi dengan adanya otonomi daerah yang memberikan kewenangan bagi daerah setempat untuk mengatur dan mengelola rumah tangganya sendiri sesuai dengan situasi dan konsisi masing-masing daerah. Persoalan sumber daya alam menjadi sangat penting ketika dikaitkan dengan implementasi otonomi daerah (B., 2012). Hal ini menjadi suatu potensi besar bagi daerah termasuk desa dalam mengola potensi sumber daya masing-masing desa dalam rangka mensejahterakan masyarakat.

Kecamatan Limbangan merupakan salah satu dari 16 Kecamatan yang berada dalam wilayah administrasi Kabupaten Kendal dengan ketinggian tanah kurang lebih 426 meter dari permukaan laut. Kecamatan Limbangan memiliki 16 desa yang mayoritas memiliki potensi sumber daya alam melimpah, salah satunya adalah Desa Pakis. Penggunaan terbesar wilayah terutama tanah di Desa Pakis adalah berupa sawah dan tanah tegalan. Tanaman pangan, perkebunan, dan peternakan merupakan beberapa jenis sumber daya di Desa Pakis. Berbagai jenis tanaman pangan yang dikembangkan di wilayah Desa Pakis antara lain padi sawah, ubi kayu, dan ubi jalar. Desa Pakis juga tergolong desa penghasil padi terbanyak di Kecamatan Limbangan.
Sementara itu, tanaman perkebunan yang menjadi potensi utama sumberdaya lokal di Desa Pakis adalah aren. Pohon aren menghasilkan produk berupa kolang kaling dan gula aren. Kedua produk tersebut menjadi produk unggulan di Desa Pakis. Namun upaya pengembangan potensi wilayah dan produk unggulan tersebut belum dilakukan secara optimal. Hal tersebut disebabkan karena keterbatasan informasi pasar dan teknologi untuk pengembangan produk, belum adanya sikap dan jiwa kewirausahaan dari pelaku pengambangan kawasan di Desa Pakis, belum berkembangnya infrastruktur kelembagaan yang berorientasi pada pengelolaan pengembangan usaha yang berkelanjutan dalam perekonomian daerah, masih terbatasnya akses petani dan pelaku usaha skala kecil terhadap modal pengembangan usaha, kurangnya upaya pemasaran produk unggulan, serta belum optimalnya pemanfaatan kerangka kerja sama antarwilayah untuk mendukung peningkatan daya saing dan produk unggulan.

Berdasarkan observasi dan forum group discussion yang dilakukan dengan pemerintah Desa Pakis maka didapatkan beberapa masalah dalam bidang pengembangan ekonomi masyarakat. Dua masalah utama yang dihadapi adalah kurangnya penguatan pola pikir ekonomi masyarakat dalam pengelolaan potensi sumber daya lokal dan belum optimalnya kerja sama antardesa yang mendukung dalam peningkatan daya saing produk unggulan. Padahal lokasi wilayah Desa Pakis termasuk wilayah yang strategis karena bersebelahan dengan desa wisata, yaitu Desa Gondang. Peluang tersebut seharusnya ditangkap oleh masyarakat untuk pengembangan pemasaran produk sehingga segmen pasar produk unggulan Desa Pakis tidak terbatas pada konsumen pasar namun juga wisatawan.

Berikut adalah analisis SWOT dari potensi perkebunan di Desa Pakis. 
Tabel 1. Analisis SWOT Potensi Perkebunan Desa Pakis

\begin{tabular}{|c|c|c|}
\hline & Strength (Kekuatan) & Weakness (Kelemaha \\
\hline Internal & $\begin{array}{l}\text { a. Melimpahnya hasil perkebunan, } \\
\text { khususnya aren. } \\
\text { b. Ketersediaan lahan } \\
\text { pengembangan. }\end{array}$ & 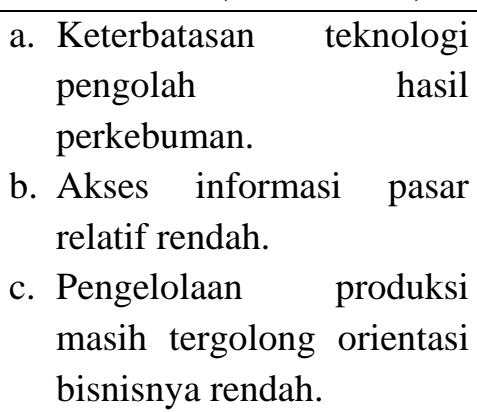 \\
\hline Opportunity (Peluang) & i “S - O" & Strategi “W - O” \\
\hline $\begin{array}{ll}\text { a. } & \text { Dukungan pemerintah. } \\
\text { b. Permintaan terhadap } \\
\text { produk kolang kaling } \\
\text { tinggi. } \\
\text { c. Peluang informasi pasar } \\
\text { semakin besar dengan } \\
\text { pemanfaatan online shop. } \\
\text { d. Peluang akses pasar } \\
\text { melalui kerjasama } \\
\text { dengan Desa Wisata } \\
\text { Gondang. }\end{array}$ & $\begin{array}{l}\text { a. Meningkatkan keahlian petani } \\
\text { aren. } \\
\text { b. Mendorong terbentuknya IKM } \\
\text { berbasis sumberdaya lokal. } \\
\text { c. Pendampingan secara langsung } \\
\text { baik pendampingan teknis } \\
\text { maupun tenaga ahli. } \\
\text { d. Pembentukan kelompok usaha } \\
\text { bersama. } \\
\text { e. Peningkatan penguasaan } \\
\text { teknologi informasi. } \\
\text { f. Pembentukan kerja sama } \\
\text { antardesa. }\end{array}$ & 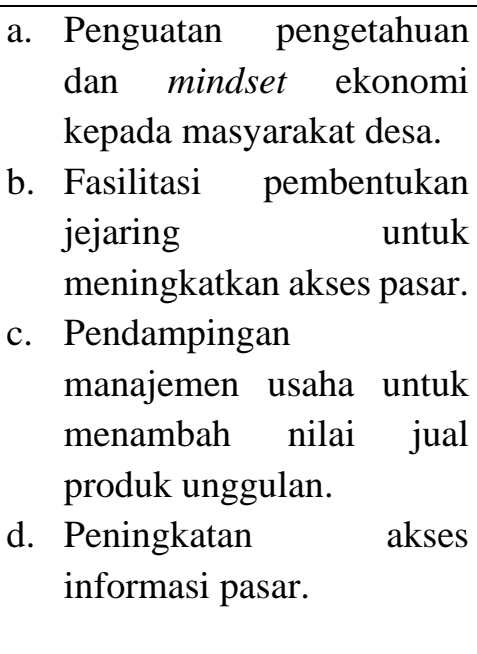 \\
\hline Threat (Ancaman) & Strategi “S - T” & ;i “W - T” \\
\hline $\begin{array}{l}\text { a. Kondisi pasar yang } \\
\text { fluktuatif. } \\
\text { b. Adanya kemungkinan } \\
\text { produk yang sama dari } \\
\text { wilayah lain. }\end{array}$ & $\begin{array}{l}\text { a. Modernisasi proses produksi } \\
\text { berbahan kolang kaling. } \\
\text { b. Meningkatkan efisiensi } \\
\text { sehingga daya saing } \\
\text { meningkat. } \\
\text { c. Memperkuat jalur permodalan, } \\
\text { distribusi, dan aspek bisnis } \\
\text { yang lainnya. } \\
\text { d. Peningkatan promosi. }\end{array}$ & $\begin{array}{ll}\text { a. } & \text { Fasilitasi standarisasi } \\
& \text { kualitas bahan baku. } \\
\text { b. } & \text { Peningkatan mutu } \\
\text { produk. }\end{array}$ \\
\hline
\end{tabular}

Berdasarkan hasil analisis SWOT tersebut menunjukkan perlunya peningkatan sumber daya manusia di Desa Pakis terutama dalam hal penguatan mindset dan literasi ekonomi. Berdasarkan latar belakang permasalahan mitra dan mempertimbangkan peluang mitra maka pengabdian ini difokuskan pada:

1. Penguatan mindset dan pengetahuan ekonomi masyarakat Desa Pakis.

2. Peningkatan pengetahuan masyarakat mengenai keuntungan diversifikasi produk olahan kolang kaling sehingga meningkatkan nilai jual produk.

3. Pendampingan pengelolaan produk olahan kolang kaling melalui proses produksi yang berbeda.

4. Peningkatan pengetahuan masyarakat Desa Pakis terkait manajemen bisnis, mulai dari perencanaan produksi sampai dengan pemasaran. 


\section{KAJIAN PUSTAKA}

Pada prinsipnya literasi ekonomi merupakan alat untuk mencapai tujuan, hanya saja pada kenyataannya tidak semua orang memiliki literasi ekonomi yang tinggi sehingga mengerucutkan peluang mencapai kesejahteraan (Sina, 2012). Sejalan dengan Zulatsari \& Soesatyo (2018) yang menyatakan bahwa literasi ekonomi menjadi salah satu hal yang penting dimiliki oleh seseorang untuk dapat mewujudkan tujuan utama dalam berekonomi, yakni memperoleh kesejahteraan. Selain itu, literasi juga mampu menumbuhkan jiwa kewirausahaan yang kuat pada masyarakat (Thohir et al., 2016; Zulatsari \& Soesatyo, 2018). Yang dimaksud dengan kewirausahaan sendiri adalah kemampuan sesorang dalam meningkatkan pendapatan kegiatan usahanya dengan terus berkreasi dan berinovasi (Sukoco, Fordian, \& Rusdin, 2020). Istilah mindset ekonomi tidak lepas dengan istilah entrepreneurial mindset. Enterpreneurial mindset mengindikasikan cara berpikir tentang bisnis dan memanfaatkan peluangnya dalam kondisi ketidakpastian (Sina \& Manane, 2020). Hal itu menggambarkan perilaku inovatif untuk memanfaatkan peluang dan segera mengambil tindakan nyata untuk mengeksplorasi. Keberadaan entrepreneurial mindset penting untuk menentukan daya saing organisasi serta masyarakat dan penciptaan lapangan kerja.

Penguatan mindset ekonomi bagi masyarakat Desa Pakis juga didukung dengan adanya potensi sumber daya alam yang belum dikelola secara optimal, terutama produk kolang kaling. Potensi sumber daya alam tanaman aren menjadi peluang yang besar dalam membangun bisnis. Kolang kaling merupakan produk olahan yang berasal dari pohon aren. Kolang kaling diperoleh dari buah aren setengah matang yang dibakar atau direbus. Saat ini produk kolang kaling hanya dipasarkan bergitu saja tanpa adanya diversifikasi produk olahan. Padahal kolang kaling bisa diolah kembali menjadi produk olahan lain yang bisa meningkatkan nilai jual produk kolang kaling. Upaya meningkatkan pemanfaatan buah kolang kaling agar memiliki nilai ekonomis dan kandungan karbohidrat pada buah kolang kaling cukup tinggi maka perlu pemanfaatannya sebagai pangan fungsional yang bermanfaat bagi kesehatan (Purwati \& Nugrahini, 2018). Penelitian Yenrina et al., (2016) juga menggunakan kolang kaling sebagai bahan penelitian dan menemukan komposisi produk terbaik dengan komposisi kolang kaling sebesar 70\% dan selai kulit buah naga sebesar 30\% . Hal ini menunjukkan bahwa kolang kaling merupakan salah satu bahan pangan yang memiliki kualitas tinggi.

Kandungan yang dimiliki oleh kolang kaling sangat bermanfaat untuk kesehatan sehingga menjadi fungsi ganda dari kolang kaling, yaitu sebagai pangan sekaligus kesehatan tubuh. Kedua hal tersebut saling terkait karena keadaan kesehatan seseorang pada setiap tahap daur kehidupan dipengaruhi secara langsung oleh konsumsi makanan (Damayanti, Pritasari, \& Lestari, 2017). Berikut adalah kandungan kolang kaling tiap $100 \mathrm{~g}$.

\section{Tabel 2. Kandungan Kolang Kaling Tiap} $100 \mathrm{~g}$

\begin{tabular}{|l|l|l|}
\hline \multicolumn{2}{|l|}{ Komposisi } & Jumlah \\
\hline Energi & $(\mathrm{kkal})$ & 27 \\
Karbohidrat & (g) & 6 \\
Serat & (g) & 1,6 \\
Protein & $(\mathrm{g})$ & 0,4 \\
Lemak & $(\mathrm{g})$ & 0,2 \\
Fosfor & $(\mathrm{ppm})$ & 24,3 \\
Kalsium & $(\mathrm{ppm})$ & 9,1 \\
Zat Besi & $(\mathrm{ppm})$ & 0,05 \\
\hline
\end{tabular}

Sumber: Ratima (2014)

Nilai lebih dari kolang kaling menjadi sebuah peluang usaha yang menjanjikan bagi masyarakat Desa Pakis untuk meningkatkan daya ekonomi masyarakat. Pertumbuhan ekonomi merupakan sebuah indikator untuk menilai kemajuan perekonomian sebuah daerah dan atas dasar ini maka setiap daerah berusaha untuk meningkatkan angka pertumbuhan ekonomi. Ide-ide kreatif menjadi suatu hal yang penting untuk meningkatkan potensi ekonomi masyarakat (HT, 2017). 


\section{TUJUAN}

Kegiatan pengabdian ini dilakukan dengan tujuan sebagai berikut: (1) meningkatan kesadaran masyarakat Desa Pakis, Kecamatan Limbangan, Kabupaten Kendal terkait literasi ekonomi; (2) memberikan tambahan pengetahuan tentang edukasi pengolahan kolang kaling; (3) meningkatkan pemahaman tentang pentingnya nilai tambah suatu produk untuk meningkatkan ekonomi masyarakat Desa Pakis; (4) memberikan praktek atau pelatihan dan pendampingan pengolahan produk kolang kaling menjadi diversifikasi produk yang memiliki nilai jual lebih tinggi.

\section{METODE}

Berdasarkan permasalahan mitra dan solusi yang ditawarkan pada program pengabdian masyarakat tersebut, suatu metoda perlu dirancang dan direalisasikan untuk menjawab permasalahan mitra yang sedang terjadi. Pendekatan penyelesaian masalah yang ditawarkan untuk menyelesaikan permasalahan mitra dan digunakan dalam kegiatan pengabdian masyarakat adalah dengan metode berikut, yaitu:

a. Metode ceramah, dengan memberikan materi tentang pentingnya peningkatan ekonomi bagi masyarakat yang dilanjutkan dengan materi kewirausahaan.

b. Metode simulasi, dengan memberikan materi awal terkait keuntungan diversifikasi produk olahan kolang kaling dilanjutkan dengan simulasi pengolahan produk kolang kaling.

c. Metode praktikum, dengan memberikan kesempatan bagi peserta pengabdian untuk melakukan proses produksi produk olahan kolang kaling.

d. Metode diskusi, dengan memberikan kesempatan tanya jawab pada para peserta pengabdian mengenai hal-hal yang belum atau tidak mereka pahami.

e. Program pendampingan, ditujukan untuk membantu permasalahan-permasalan yang muncul saat para petani mencoba mengelola bisnis awal. f. Program tindak lanjut, ditujukan untuk membantu pelaku bisnis memasarkan produk dan menjalin kerja sama antardesa untuk meningkatkan jaringan pemarasan.

Kegiatan pengabdian masyarakat ini, dilaksanakan dalam berbagai tahapan sebagai berikut:

a. Tahapan persiapan kegiatan

Tahapan persiapan kegiatan dilakukan untuk menyesuaikan kebutuhan mitra, waktu pelaksanaan kegiatan pengabdian, dan tempat untuk melaksanakan kegiatan pengabdian. Termasuk di dalamnya observasi langsung terkait potensi lain yang bisa digali dimana berhubungan dengan program pengabdian masyarakat.

b. Tahapan sosialisasi

Tahapan ini didahului dengan tim pengabdi mempersiapkan materi dan bahan yang diperlukan selama proses kegiatan, diantaranya adalah power point untuk presentasi, hand out terkait dengan pemahaman yang mendasar mengenai peran perekonomian untuk kesejahteraan masyarakat, upaya yang perlu dilakukan untuk meningkatkan daya ekonomi masyarakat melalui bisnis, dan literasi kewirausahaan. Kemudian dilanjutkan pemaparan materi dengan menghadirkan narasumber yang ahli dalam bidang pengolahan pangan, khususnya diversifikasi produk olahan kolang kaling.

c. Tahapan pelatihan

Sebelum dilakukan praktik pengolahan dan pendampingan proses produksi, peserta pengabdian diberikan penyuluhan. Hal ini penting dilakukan untuk meningkatkan kinerja individu agar tujuan akhir dari pelaksanaan kegiatan pengabdian ini bisa tercapai (Susanti, Gunawan, \& Sukaesih, 2019). Pertama kali yang diberikan kepada masyarakat adalah memberikan penyuluhan mengenai potensi produk kolang kaling yang bisa diolah lebih lanjut untuk meningkatkan nilai jual produk. Selanjutnya narasumber mempraktikum proses produksi pengolahan kolang kaling 
menjadi produk yang bernilai tambah yang diikuti dengan peserta pengabdian.

d. Tahapan penyuluhan

Setelah diberikan sosialisasi dan pelatihan, pengabdi memberikan gambaran upaya memulai bisnis awal yang dimulai dari perancangan produk, produksi, pengemasan, sampai dengan pendistribusian produk.

\section{HASIL DAN PEMBAHASAN}

\section{Isi Hasil dan Pembahasan}

Pelaksanaan kegiatan pengabdian diawali dengan tahapan diskusi dengan Pemerintah Desa Pakis, Kecamatan Limbangan, Kabupaten Kendal. Berdasarkan hasil diskusi, diketahui bahwa literasi ekonomi masyarakat desa masih sangat minim. Meskipun potensi sumber daya alam yang dimiliki oleh Desa Pakis sangat melimpah, namun belum dikelola secara optimal. Salah satu produk unggulan masyarakat Desa Pakis adalah kolang kaling. Berdasarkan informasi yang diperoleh, selanjutnya tim pengabdian berdiskusi untuk melaksanakan program pengabdian dengan menekankan pada penguatan pola pikir masyarakat akan pentingnya literasi ekonomi. Kegiatan pengabdian juga memberikan pelatihan pengolahan kolang kaling menjadi produk yang memiliki nilai jual lebih tinggi.

Hasil diskusi dengan Pemerintah Desa Pakis menunjukkan bahwa masyarakat Desa Pakis masih kurang terkait dengan literasi ekonomi dan minim pengetahuannya dalam pengolahan produk kolang kaling yang merupakan salah satu potensi alam di Desa Pakis. Hampir seluruh masyarakat Desa Pakis tidak melakukan diversifikasi produk kolang kaling untuk menambah nilai jual produk. Langkah awal untuk mengatasi permasalahan pada mitra yaitu penguatan pada mindset dan literasi ekonomi. Oleh sebab itu, tim pengabdian memutuskan untuk mengadakan pengabdian dengan menekankan pada penguatan mindset ekonomi melalui pengolahan produk kolang kaling. Gambar 1 menunjukkan proses pelaksanaan pemaparan materi literasi ekonomi kepada masyarakat
Desa Pakis yang dilakukan oleh dosen pendidikan ekonomi Universitas Negeri Semarang.

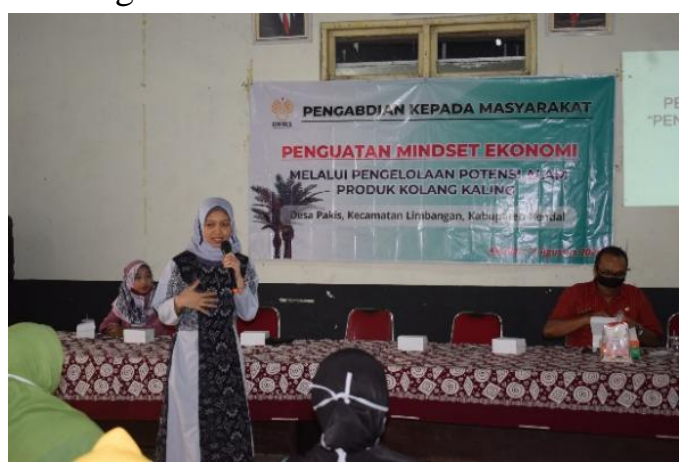

Gambar 1. Pemaparan Materi Literasi Ekonomi

Ketercapaian pengabdian ini adalah meningkatnya literasi ekonomi dan mindset ekonomi serta kesadaran masyarakat akan pentingnya penambahan nilai jual produk melalui diversifikasi. Penguatan literasi ekonomi penting dilakukan untuk menumbuhkan jiwa kewirausahaan, pemahaman yang mendasar mengenai peran perekonomian untuk kesejahteraan masyarakat, dan upaya yang perlu dilakukan untuk meningkatkan daya ekonomi masyarakat melalui bisnis. Masyarakat Desa Pakis juga dibekali dengan pengetahuan mengenai pengolahan produk kolang kaling. Gambar 2 menunjukkan proses pelaksanaan pemaparan materi mengenai cara mengolah produk kolang kaling menjadi produk yang bernilai jual tinggi.

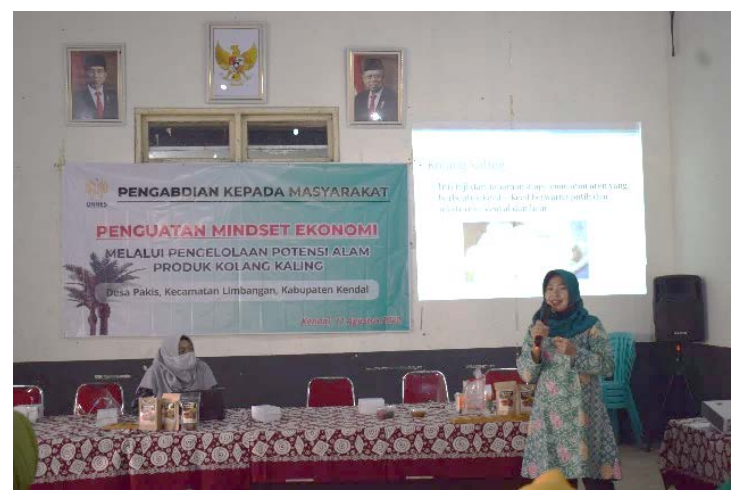

Gambar 2. Pemaparan Materi Pengolahan Produk Kolang Kaling

Melalui pengetahuan pengelolahan produk kolang kaling maka massyarakat memiliki kemampuan dalam diversifikasi produk olahan kolang kaling. Di samping 
pengetahuan dalam mengolah produk kolang kaling, tim pengabdi juga melakukan pendampingan dalam pengolahan produk kolang kaling dengan menggunakan proses produksi yang berbeda sehingga menghasilkan produk yang bernilai jual lebih tinggi. Gambar 3 dan 4 menunjukkan proses pendampingan dalam pengolahan produk.

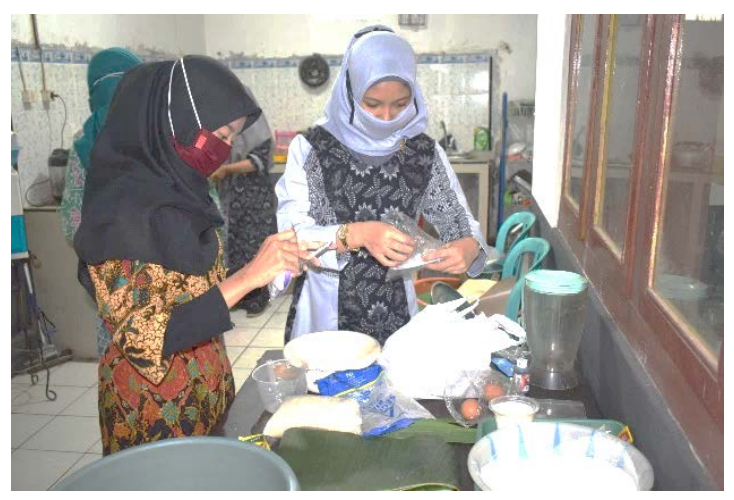

Gambar 3. Persiapan Pendampingan Pengolahan Produk Kolang Kaling

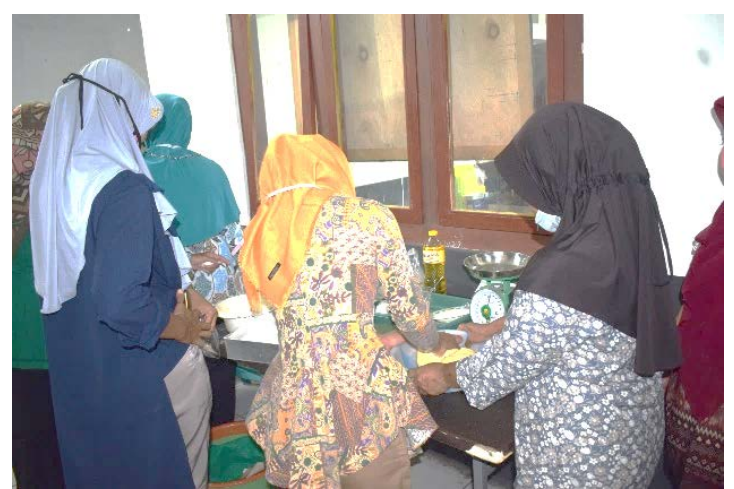

Gambar 4. Pendampingan Pengolahan Produk Kolang Kaling

Dari pendampingan yang dilakukan, tercipta beraneka produk olahan kolang kaling yang bernilai jual tinggi. Gambar 5 menunjukkan hasil olahan produk kolang kaling yang lebih menarik dan bernilai jual. Hasil olahan produk tersebut kemudian dikemas dalam tempat yang menarik dan memungkinkan untuk disimpan dalam lemari pendingin sehingga terjaga ketahanan produknya.

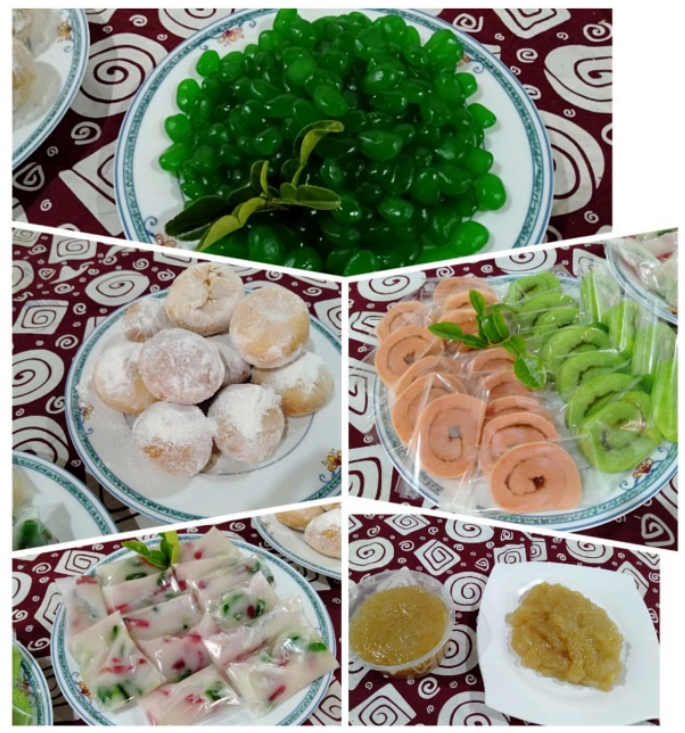

Gambar 5. Hasil Olahan Produk Kolang Kaling

Pelaksanaan kegiatan pengabdian ini secara ringkas ditampilkan pada gambar berikut ini. 


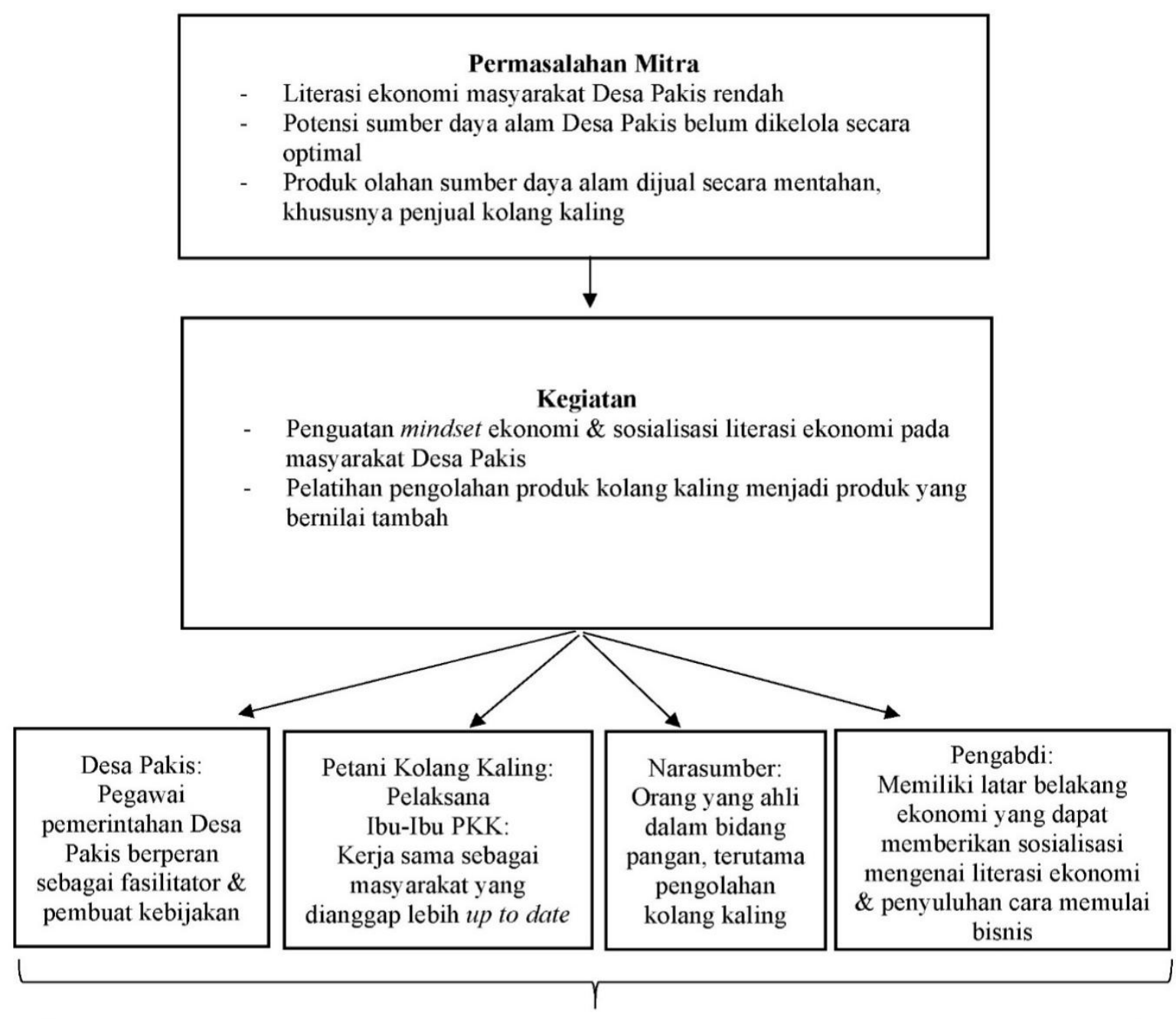

Luaran:

- Masyarakat Desa Pakis melek ekonomi

- Terciptanya produk olahan kolang kaling yang bernilai jual tinggi

- Terbentuknya kelompok usaha kolang kaling

\section{Gambar 6. Diagram Pelaksanaan Kegiatan Pengabdian}

\section{SIMPULAN}

Kegiatan pengabdian kepada masyarakat ini terbagi menjadi dua subkegiatan, di antaranya sosialisasi penguatan mindset ekonomi dan praktik pengolahan produk kolang kaling. Materi pelatihan yang dipaparkan dalam kegiatan sosialisasi penguatan mindset ekonomi berupa literasi ekonomi mengenai peran ekonomi pada masyarakat, upaya peningkatan ekonomi masyarakat, pentingnya kewirausahaan, ruang lingkup ekonomi kreatif serta motivasi untuk mengembangkan ide-ide kreatif menjadi sumber ekonomi kreatif. Melalui penyuluhan tersebut, masyarakat Desa Pakis melek terhadap ekonomi dan mampu meningkatkan ide-ide kreatifnya menjadi sumber ekonomi kreatif yang bermuara pada peningkatan kesejahteraan masyarakat. Kegiatan pengabdian kepada masyarakat ini tidak hanya terbatas pada penyuluhan yang sifatnya teoritis. Akan tetapi juga untuk memotivasi masyarakat Desa Pakis.

Berkaitan dengan gambaran ide-ide kreatif sebagai sumber ekonomi masyarakat maka pengabdi memberikan penguatan pada praktik pengelolaan produk kolang kaling. Kolang kaling dipilih sebagai bahan utama dalam praktik pengabdian ini karena kolang kaling merupakan salah satu potensi sumber daya alam Desa Pakis dan menjadi produk 
unggulan pada Desa Pakis. Selain itu kolang kaling memiliki dual fungsi yaitu sebagai pangan sekaligus kesehatan. Sebelum diberikan pelatihan praktik pengelolaan produk kolang kaling, pengabdi memberikan gambaran potensi diversifikasi produk kolang kaling menjadi beberapa olahan yang dapat memberikan nilai tambah produk kolang kaling.

Kegiatan praktek pengolahan kolang kaling dalam pengabdian ini bekerja sama dengan narasumber ahli pangan yang memberikan pelatihan praktik pengolahan produk kolang kaling menjadi beberapa olahan yang lebih bernilai jual. Melalui kegiatan pelatihan pengolahan ini masyarakat Desa Pakis termotivasi untuk melakukan diversifikasi produk kolang kaling sehingga tidak hanya menjual dalam bentuk kolang kaling mentah namun bisa memprosesnya menjadi produk yang lebih bernilai jual tinggi. Kegiatan pengabdian masyarakat ini menjadi titik awal pendampingan msyarakat Desa Pakis dan diharapkan kedepannya bisa dilakukan tindak lanjut yaitu bisa membentuk kelompok atau sentra usaha kolang kaling.

\section{UCAPAN TERIMAKASIH}

Penulis mengucapkan terima kasih kepada Lembaga Penelitian dan Pengabdian Msyarakat (LPPM) Universitas Negeri Semarang atas dukungan yang diberikan sehingga kegiatan pengabdian masyarakat dapat berjalan dengan lancar. Selain itu, penulis juga mengucapkan terima kasih kepada Pemerintah Desa Pakis selaku mitra pengabdian masyarakat atas kerja samanya sehingga tujuan kegiatan pengabdian masyarakat dapat tercapai.

\section{DAFTAR PUSTAKA}

B., J. 2012. Otonomi Daerah dan Pengelolaan Sumber Daya Alam di Propinsi Kalimantan Timur. Jurnal Borneo Administrator, 8(1), 7-30.

Basrowi, \& Juariyah, S. 2010. Analisis Kondisi Sosial Ekonomi dan Tingkat Pendidikan Masyarakat Desa Srigading, Kecamatan Labuhan Maringgai, Kabupaten Lampung Timur. Jurnal Ekonomi \&
Pendidikan, 7(1), 58-81.

Damayanti, D., Pritasari, \& Lestari, N. T. 2017. Gizi dalam Daur Kehidupan. Pusat Pendidikan Sumber Daya Manusia Kesehatan.

HT, M. A. 2017. Economic Policy Based On Creative Industries Craft Supreme Effort Lifting Local Wisdom In Distrik Tuban. Cakrawala, 11(2), 157-169.

Junaidi, J., \& Zulgani, Z. 2011. Peranan Sumberdaya Ekonomi dalam Pembangunan Ekonomi Daerah. Jurnal Pembangunan Daerah Edisi III, O(0), 27-33.

Purwati, \& Nugrahini, T. 2018. Pemanfaatan Buah Kolang Kaling dari Hasil Perkebunan sebagai Pangan Fungsional. Jurnal Abdimas Mahakam, 2(1), 24-33.

Ratima. 2014. Khasiat Tersembunyi Kolangkaling. Tabloit Sinar Tani. https://tabloidsinartani.com/detail/i ndeks/olahan-pasar/612-khasiattersembunyi-kolang-kaling.

Sina, P. G. 2012. Analisis Literasi Ekonomi. Jurnal Economia, 8(2), 135-143.

Sina, P. G. \& Manane, D.R. 2020. Pengaruh Literasi Keuangan dan Mindset Berwirausaha terhadap Komitmen Organisasi. Jurnal inspirasi Ekonomi, 2(2), 17-24.

Sukoco, I., Fordian, D., \& Rusdin. (2020). Pelatihan Dasar Dan Workshop Kewirausahaan Di Desa Cintaratu Kabupaten Pangandaran. Kumawula: Jurnal Pengabdian Kepada Masyarakat, 2(3), 248-261. https://doi.org/10.24198/kumawula.v2i3. 24706

Susanti, S., Gunawan, W., \& Sukaesih. (2019). Pengembangan Pemasaran Bordir dan Kelom Geulis Tasikmalaya Melalui Media Sosial. Jurnal Kumawula: Jurnal Pengabdian Kepada Masyarakat, 2(3), 248-261. https://doi.org/http://10.24198/kumawula. vli3.25256 
Thohir, M., Soesatyo, Y., \& Harti. 2016. Pengaruh Status Sosial Ekonomi Oeang Tua, Literasi Ekonomi, dan Percaya Diri terhadap Minat Wirausaha Siswa SMP Negeri di Kecamatan Tenggilis Mejoyo Surabaya. Jurnal Ekonomi Pendidikan Dan Kewirausahaan, 4(2), 149-163.

Yenrina, R., Azima, F., \& Khumairoh., F. 2016. Betacyanin Content and Antioxidant Activity of Slice Jam Mixture of KolangKaling (Arenga Pinnata) and Dragon Fruit Peel (Hylocereus Polyrhizus). International Journal of Advanced Research, 4(12), 1223-1229.

Zulatsari, M. R., \& Yoyok Soesatyo. 2018. Pengaruh Literasi Ekonomi Dan Pendidikan Kewirausahaan Terhadap Minat Berwirausaha Pada Mahasiswa Jurusan Pendidikan Ekonomi Fakultas Ekonomi Universitas Negeri Surabaya Angkatan 2015. Jurnal Pendidikan Ekonomi, 6(3), 157-160. 